\title{
PENGEMBANGAN MOBILE LEARNING MENGGUNAKAN ADOBE FLASH PADA PELAJARAN NARRATIVE TEXT DI SMP ELKISI MOJOKERTO
}

\author{
Ardhian Zahroni \\ Pasca Sarjana Teknologi Pendidikan, Universitas PGRI Adibuana Surabaya \\ ardhianzahroni@gmail.com
}

\begin{abstract}
English is an important thing to learn by students, because English is an international language. However, English learning in nine grade of eLKISI Junior High School has not been optimally. There are several obstacles that cause learning English to be less than optimal. Such as lack students motivation, limited learning hours, and inexperienced teachers. To solve these problems it is necessary to make product of learning media in the form of android-based applications. Android-based applications are commonly used so that Android-based applications will be easy to use by people. The product contains English narrative text lessons for class IX in Junior High School. Development uses Adobe Flash CS6 software to produce interesting learning media equipped with animation, images and sound. This research and development use the ADDIE development design model. Development products are reviewed by material experts, instructional media experts and learning designs, and tested by students (small groups and large groups), as well as field trials (tryout). The use of applications is done with a variety of places, it can be concluded that the use of applications can be done at any moment. In terms of ease of use of the application, all respondents answered that there were no difficulties.
\end{abstract}

Keywords: Development of teaching materials, ADDIE, Mobile learning, English Learning

\begin{abstract}
Abstrak
Bahasa Inggris adalah hal yang penting untuk dipelajari oleh siswa, karena bahasa Inggris adalah bahasa internasional. Namun pembelajaran bahasa Inggris di kelas sembilan SMP eLKISI belum optimal. Ada beberapa kendala yang menyebabkan pembelajaran bahasa Inggris menjadi kurang optimal. Seperti kurangnya motivasi siswa, jam belajar yang terbatas, dan guru yang tidak berpengalaman. Untuk mengatasi masalah tersebut perlu dibuat produk media pembelajaran dalam bentuk aplikasi berbasis android. Aplikasi berbasis Android sudah banyak dipergunakan sehingga akan mudah digunakan oleh orang. Produk ini berisi pelajaran teks naratif bahasa Inggris untuk kelas sembilan di SMP. Pengembangan menggunakan perangkat lunak Adobe Flash CS6 untuk menghasilkan media pembelajaran yang menarik, dilengkapi dengan animasi, gambar, dan suara. Penelitian dan pengembangan ini menggunakan model desain pengembangan ADDIE. Produk pengembangan ditinjau oleh para ahli materi, ahli media pembelajaran dan desain pembelajaran, dan diuji oleh siswa (kelompok kecil dan kelompok besar), serta uji coba lapangan (uji coba).
\end{abstract}

Nidhomul Haq: Jurnal Manajemen Pendidikan Islam

ISSN: 2503-1481 Hal: 90-103

DOI: $10.31538 /$ ndh.v4i1.237 
Penggunaan aplikasi dilakukan di berbagai tempat, dapat disimpulkan bahwa penggunaan aplikasi dapat dilakukan setiap saat. Seluruh responden menjawab tidak ada kesulitan dalam penggunaan aplikasi.

Kata Kunci: Pengembangan media pembelajaran, ADDIE, Mobile learning, pembelajaran bahasa inggris

\section{PENDAHULUAN}

Teknologi handphone saat ini telah memasuki era smartphone. Handphone tidak hanya dipakai untuk komunikasi verbal, namun memiliki berbagai keunggulan dan kelebihan. Saat ini handphone dengan ukuran yang relatif kecil dapat menampilkan audio visual serta dapat terhubung dengan internet. Selain itu handphone memiliki kemampuan untuk mendeteksi posisi sekaligus menghitung seberapa jauh tempat yang akan dituju. Handphone juga memiliki kemampuan mengetahui kondisi lingkungan termasuk tingkat cahaya, suhu, tekanan, dan medan magnet. Kemampuan penting yang lain dari fitur handphone adalah kemampuan berkomunikasi dengan alat lain dengan berbagai macam cara termasuk menggunakan Wi-Fi maupun Bluetooth ${ }^{1}$.

Dengan kecanggihan perkembangan handphone tersebut, maka handphone saat

\footnotetext{
${ }^{1}$ Iversen, J., \& Eierman, M. Learning Mobile App Development A Hands-on Guide to Building Apps with iOS and Android. Indiana: Addison-Wesley, 2014.
}

ini juga dimanfaatkan untuk media pembelajaran. Pembelajaran yang memanfaatkan fasilitas handphone bisa disebut sebagai mobile learning, yaitu pembelajaran yang bersifat bergerak dan tidak dibatasi oleh tempat dan waktu. Pemanfaatan handphone sebagai mobile learning menjadikan pendidikan lebih kreatif, efektif, dan optimal. Mobile learning adalah cara baru dalam belajar dengan pendekatan pembelajaran yang melibatkan piranti bergerak seperti handphone, Personal Digital Assistant (PDA), laptop dan tablet. Dimana pelajar dapat mengakses materi dan arahan dari guru tanpa dibatasi oleh ruang dan waktu. Perangkat m-learning menggunakan peralatan portable membuat pembelajaran menjadi mudah berpindah, tidak dibatasi kelas, bersifat pribadi, dan menarik. Penggunaan teknologi ini ternyata selaras dengan strategi tujuan pendidikan seperti meningkatkan prestasi siswa, menjadi solusi sumber belajar yang efektif, dan menjangkau seluruh siswa untuk memiliki 
kesempatan berpartisipasi dalam pendidikan ${ }^{2}$.

Mobile learning dapat menjadi media pembelajaran yang mengoptimalkan jembatan komunikasi antara guru dengan siswa. Dengan adanya mobile learning maka tidak akan ada kendala keterbatasan waktu pembelajaran hanya di kelas. Pembelajaran dapat diakses dari mana saja dana kapan saja, tanpa dibatasi jam dan lokasi sekolah.

Demikian pula penyampaian materi melalui mobile learning akan lebih menarik karena didukung oleh fasilitas teks dan audio visual. Materi pelajaran menggunakan media mobile learning dapat dilengkapi dengan video pembelajaran, animasi, dan suara sehingga pembelajaran akan berlangsung dengan atraktif. Materi maupun soal dapat dibuat interaktif sehingga siswa tidak akan bosan. Selain itu siswa dapat bereksplorasi menggunakan fasilitas internet melalui akses link pembelajaran yang terkait dengan artikel, makalah, jurnal, video dari seluruh dunia. Sehingga siswa dapat mempelajari materi pembelajaran dengan menyenangkan.

Mobile learning dapat pula dipergunakan untuk pembelajaran bahasa inggris. Terdapat berbagai penelitian yang membahas manfaat penggunaan mobile learning dalam pembelajaran bahasa inggris. Hasil penelitian tersebut menunjukkan bahwa mobile

2 Kukulska, H., \& Traxler, J. Mobile Learning A handbook for educators and trainers. London: Routledge, 2005. learning adalah media pembelajaran yang efektif, efisien, dan nyaman untuk dipergunakan dalam pembelajaran bahasa inggris ${ }^{3}$.

Penggunaan mobile learning dalam proses pembelajaran pada hakikatnya adalah sebagai media dalam proses komunikasi. Dimana penyampaian pesan dari sumber pesan ke penerima pesan terdapat media komunikasi, maka mobile learning dalam hal ini adalah sebagai media komunikasi tersebut. Terdapat berbagai macam strategi dan metode pembelajaran yang bisa diterapkan guru dalam meningkatkan kualitas pembelajarannya. Menurut Dick and Carey bahwa strategi pembelajaran adalah suatu perangkat materi dan prosedur pembelajaran yang digunakan secara bersama-sama untuk menimbulkan hasil belajar pada siswa. Agar strategi pembelajaran yang direncanakan tersebut dapat berhasil, maka guru harus menentukan meetode pembelajaran apa yang perlu diterapkan. Sebagian besar guru di sekolah masih menggunakan metode pembelajaran ceramah yang dibarengi dengan metode tanya jawab dan diskusi. Sedangkan penggunaan media dalam kegiatan pembelajaran masih kurang, hal ini

\footnotetext{
${ }^{3}$ Socket, G. New Language Learning \& Teaching Environments The Online Informal Learning of English. Paris: Pagrave Macmillan, 2014.
} 
menyebabkan hasil pembelajaran kurang optimal $^{4}$.

Bahasa inggris merupakan pelajaran yang sangat penting untuk dipelajari siswa. Karena bahasa inggris pada di era globalisasi dipakai diberbagai bidang kehidupan. Bahasa inggris merupakan bahasa internasional, sehingga siswa butuh mempelajari dan menguasai bahasa inggris dengan baik. Saat ini persaingan usaha tidak hanya terjadi di wilayah lokal atau regional semata, namun meluas ke dunia internasional. Penguasaan bahasa inggris merupakan komponen penting dalam menghadapi persaingan global tersebut. Dalam waktu dekat di bidang perdagangan diterapkan MEA (Masyarakat Ekonomi Asean). Dalam waktu yang tidak lama akan terealisasi globalisasi dimana dunia akan menjadi desa global (global village). Sehingga akan terjadi persaingan antara warga negara asli dan warga negara asing. Untuk itu diperlukan keterampilan yang handal, termasul dalam keterampilan berkomunikasi menggunakan bahasa inggris.

Namun demikian terdapat kendala siswa dalam menguasai pelajaran Bahasa Inggris. Kendala yang dihadapi siswa dalam mengikuti pelajaran Bahasa Inggris antara lain keterbatasan jam pelajaran. Siswa mengikuti pelajaran Bahasa Inggris dengan

\footnotetext{
${ }^{4}$ Dickins, P. R. Evaluation (Language Teaching : a Scheme for Teacher Education). Oxford: Oxford University Press. 1993.
}

guru dengan alokasi waktu 4 x 40 menit seminggu. Alokasi waktu tersebut terhitung singkat sehingga materi yang disampaikan oleh guru tidak tuntas.

Metode konvensional banyak dilakukan oleh guru. Guru seringkali menggunakan metode ceramah tanpa ada media pembelajaran selain buku dan papan tulis. $\mathrm{Hal}$ ini seringkali menjadikan siswa cenderung bosan dan tidak memperhatikan materi yang disampaikan oleh guru. Terdapat siswa yang kurang bersemangat dalam mengikuti proses belajar mengajar. Siswa terlihat pasif dan tidak memberikan umpan balik saat guru menyampaikan materi dan memberikan tugas. Siswa bersifat pasif dengan menunggu penyampaian dari guru daripada berusaha untuk menemukan sendiri pengetahuan, keterampilan atau sikap yang mereka butuhkan.

Guru perlu mengupayakan strategi pembelajaran yang tepat untuk mencapai tujuan pembelajaran. Guru harus menentukan strategi pembelajaran yang tepat agar pembelajaran dapat berjalan dengan baik. Salah satu strategi pembelajaran yang dapat dipergunakan adalah dengan menggunakan mobile learning sebagai media pembelajaran.

Berdasarkan analisis dan hasil observasi yang dilakukan terhadap pembelajaran Bahasa Inggris di SMP eLKISI, maka perlu adanya inovasi baru dalam proses 
pembelajaran untuk menarik minat belajar siswa. Perlu adanya metode pembelajaran baru yang dapat meningkatkan hasil belajar lebih baik. Maka perlu dikembangkan mobile learning (M-learning) untuk pelajaran Bahasa Inggris. Media pembelajaran yang digunakan memanfaatkan handphone android yang dipergunakan sebagai fasilitas mobile learning. M-learning dapat membantu siswa menambah pemahaman terhadap materi pembelajaran Bahasa Inggris karena dapat dipelajari secara berulang-ulang tanpa terbatas ruang dan waktu. Dengan mobile learning siswa dapat menyesuaikan waktu tambahan untuk belajar atau mengisi waktu pembelajaran yang terlewatkan.

Pengembangan mobile learning menggunakan model desain pengembangan ADDIE (Analyze, Design, Development, Implementation, Evaluation). Mobile learning menggunakan fasilitas handphone berbasis android. Pengembangan mobile learning dibuat dengan software Adobe Flash CS6. Software Adobe Flash CS6 dapat membuat materi secara bervariasi dengan tampilan teks, audio, video, animasi, dan latihan soal. Penyajian materi yang bervariasi dapat menunjang proses pembelajaran dimana siswa menjadi lebih aktif. Mobile learning memberi banyak waktu dan kesempatan kepada siswa untuk dapat belajar lebih banyak. Pemanfaatan mobile learning akan dapat memotivasi peningkatan kualitas pembelajaran dan menarik minat siswa dalam proses pembelajaran.

\section{LANDASAN TEORI}

Media pembelajaran didefinisikan sebagai perantara antara terjadinya komunikasi dari pengirim menuju penerima yang mencakup semua sumber yang diperlukan berupa hardware dan software, meliputi manusia, materi atau kajian untuk membangun suatu kondisi yang membantu siswa memperoleh pengetahuan, keterampilan, dan sikap.

Cakupan dari media pembelajaran sangat luas meliputi manusia dan materi kajian. Dengan media pembelajaran tersebut akan mampu membuat siswa memperoleh pengetahuan, keterampilan atau sikap yang diharapkan. Sumber yang diperlukan oleh media pembelajaran dalam rangka melakukan komunikasi antara guru dan siswa dalam pembelajaran. Bentuk media pembelajaran bisa berupa perangkat keras (hardware), seperti komputer, TV, proyektor. Bisa juga dalam bentuk perangkat lunak (software) yaitu program aplikasi yang digunakan dalam perangkat keras itu ${ }^{5}$.

Mobile learning menurut Wikipedia adalah mempelajari berbagai hal melalui interaksi sosial dan pertukaran materi menggunakan perangkat elektronik pribadi. Mobile learning didefinisikan sebagai suatu

\footnotetext{
${ }^{5}$ Smaldino, S. E. Instructional Technology and Media for Learning. New Jersey: Pearson Merrill Prentice Hall, 2003.
} 
bentuk pendidikan jarak jauh perpaduan antara komputasi bergerak dan e- learning menjadi sumber yang dapat diakses dimana saja, mempermudah pencarian informasi dan interaksi sehingga sangat mendukung pembelajaran yang efektif tanpa batasan ruang dan waktu'.

Mobile learning memanfaatkan model pembelajaran berbasis teknologi informasi dan komunikasi. Konsep pembelajaran menggunakan mobile learning menjadikan materi ajar dapat diakses oleh siswa setiap saat. Materi dalam mobile lear \ning bisa berupa materi teks, audio visual, atau animasi yang menarik. Mobile learning merupakan salah satu cabang dari e-learning, dimana mobile learning lebih spesifik menggunakan kecanggihan handphone (smartphone) sebagai perangkat pembelajarannya. Mobile learning dapat diakses dimana saja dan kapan saja dengan tampilan yang menarik.

Mobile learning dapat meningkatkan motivasi belajar siswa karena materi pembelajarannya disajikan lebih menarik dibandingkan dengan pembelajaran konvensional. Hal ini akan mendorong siswa untuk aktif belajar secara mandiri tanpa dibatasi waktu dan ruang. Sehingga terwujud pembelajaran sepanjang hayat (life long

${ }^{6}$ Kukulska, A., \& Hulme. Will Mobile Learning Change Language Learning? European Association for Computer Assisted Language Learning, 157-165, 2009. learning). Mobile learning juga memungkinkan terjadinya interaksi secara intens antara guru dengan siswa, ataupun sesama siswa dalam rangka pembelajaran.

M-Learning dapat digunakan untuk menjelaskan permasalahan sistem pembelajaran konvensional. Guru dan siswa, keduanya memerlukan sistem yang tepat dan berguna untuk saling berinteraksi dan memfasilitasi sistem pembelajaran. Mobile learning tidak dapat menggantikan kelas tradisional tetapi dapat digunakan sebagai pelengkap dalam proses pembelajaran di kelas dan universitas ${ }^{7}$.

Mobile Learning dapat menggunakan media pembelajaran berupa handphone berbasis android. Perkembangan teknologi handphone berbasis android demikian tinggi dengan fungsi yang menyerupai computer, maka handphone berbasis android disebut juga sebagai telepon pintar atau smartphone. Kecanggihan smartphone dapat dimanfaatkan dalam dunia pendidikan, dimana smartphone digunakansebagai media penunjang pembelajaran. Pembelajaran diharapkan akan menjadi menarik karena dirasa lebih interaktif, yaitu dilengkapi dengan gambar, suara, animasi, dan adanya interaktif penggunanya.

\footnotetext{
${ }^{7}$ Iversen, J., \& Eierman, M. Learning Mobile App Development A Hands-on Guide to Building Apps with iOS and Android. Indiana: Addison-Wesley, 2014.
} 
Mobile learning berisi materi Bahasa Inggris tema narrative teks untuk kelas IX. Bahasa Inggris adalah pelajaran yang penting untuk dipelajari oleh siswa. Dimana bahasa inggris merupakan alat untuk berkomunikasi di dunia international. Kemampuan berkomunikasi menggunakan bahasa inggris yakni kemampuan memahami dan atau menghasilkan teks lisan dan atau tulisan. Terdapat empat kompetensi bahasa inggris yang perlu diwujudkan dalam ketrampilan berbahasa yaitu mendengarkan, berbicara, membaca dan menulis. Keempat ketrampilan inilah yang perlu untuk dikuasai oleh siswa sehingga siswa memiliki daya saing unggul di tingkat internasional.

Pembelajaran Bahasa Inggris memiliki prinsip dalam standar isi. Pembelajaran bahasa inggris tersebut selain ditujukan sebagai alat komunikasi, juga agar siswa memiliki kompetensi yang berdaya saing global. Pembelajaran Bahasa Inggris dilaksanakan dengan melibatkan siswa dan konteks lingkungannya sehari-hari. Penguasaan Bahasa Inggris oleh siswa bukan malah memudarkan budaya lokal, namun justru memperkokoh budaya lokal sekaligus mengenal dan memahami budaya internasional. Penguasaan Bahasa Inggris akan menjadi sarana untuk meningkatkan penguasaan ilmu pengetahuan, dan teknologi (IPTEK), sehingga sumber daya manusia Indonesia akan meningkat di tingkat internasional.
Pembelajaran Bahasa Inggris di SMP eLKISI Mojokerto berdasarkan kurikulum 2006. Dalam penelitian ini mengambil tema Narrative Text di Kelas IX. Proses pembelajaran Bahasa Inggris di SMP eLKISI Mojokerto menggunakan metode yang biasa digunakan guru dalam mengajar (tatap muka) dengan proses pembelajaran yang menggunakan metode pembelajaran dengan bantuan mobile learning berbasis android.

\section{METODE PENELITIAN}

Pengembangan media pembelajaran berbasis smartphone berbasis Android untuk pembelajaran Bahasa Inggris Narrative Text Kelas IX SMP mengacu pada model pengembangan ADDIE (Analyze, Design, Development, Implement, Evaluation $)^{8}$.

\section{Analisis (Analyze)}

Tahap analisis berfokus pada target audiens. Pada tahap ini dilakukan pendefinisian permasalahan yang terjadi di lapangan, merumuskan tujuan instruksional, menentukan sasaran pembelajaran, serta melakukan identifikasi kondisi pengetahuan yang dimiliki oleh siswa dan lingkungan pembelajaran yang ada.

Proses penelitian dan pengumpulan informasi dilakukan untuk mengumpulkan data tentang materi pelajaran Bahasa Inggris

\footnotetext{
8 Setyosari, P. Metode Penelitian Pendidikan \& Pengembangan. Jakarta: KENCANA, 2013.
} 
pokok bahasan Narrative Text. Data yang dibutuhkan meliputi gambar, materi pelajaran, dan soal-soal latihan, yaitu semua materi tersebut akan dijadikan bahan pembuatan aplikasi mobile learning berbasis android.

\section{Desain Pengembangan (Design)}

Tahap desain adalah menentukan sasaran, membuat instrumen penilaian, membuat instrumen latihan, membuat isi materi, dan melakukan analisa yang terkait materi pembelajaran, membuat rencana pembelajaran dan memilih media yang akan dibuat. Fase desain dilakukan secara berurutan, spesifik, dan sistematik.

\section{Pengembangan (Development)}

Tahap pengembangan yaitu melakukan pembuatan dan penggabungan isi materi yang sudah dirancang pada tahapan desain. Pada tahap ini membuat alur rangkaian materi (storyboard), menuliskan isi materi dan merancang grafis yang diperlukan.

Tahap pengembangan aplikasi mobile learning digunakan untuk mengubah naskah yang telah disusun sebelumnya menjadi sebuah program yang berisi gambar, teks, suara, dan animasi dengan format yang kompatibel dengan smartphone berbasis android. Proses produksi mobile learning berbasis android dibagi menjadi tiga tahap yaitu tahap pra produksi, produksi, dan pasca produksi.
4. Implementasi (Implement)

Fase implementasi yaitu membuat prosedur untuk pelatihan bagi siswa dan guru. Pelatihan bagi guru meliputi cara implementasi software di android, hasil pembelajaran yang diharapkan, metode penyampaian dan prosedur pengujian. Pada tahap ini juga dilakukan instalasi software di android guru dan siswa. Perlu dilakukan tindakan antisipasi terkait dengan masalah teknis apabila terjadi di waktu implementasi produk. Juga dilakukan diskusi terkait dengan rencana alternatif pada pihak guru dan siswa.

Uji coba produk dilakukan setelah produk divalidasi oleh para ahli, baik ahli media maupun ahli materi. Dan setelah dinilai oleh siswa. Produk diujicobakan kepada sampel, yaitu kelas IX SMP eLKISI. Subyek uji coba melakukan pembelajaran menggunakan mobile learning dan memberikan penilaian terhadap produk tersebut.

Tahap implementasi ini dilakukan dengan melakukan Uji coba secara riil penggunaan aplikasi android di handphone siswa. Karena produk pengembangan merupakan mobile learning, penggunaan mobile learning tersebut idealnya adalah dilakukan oleh siswa secara mandiri, tanpa ada batasan lokasi maupun waktu. Sehingga pengujian dilakukan di luar jam sekolah dengan mengambil sampel 6 siswa yang 
sebelumnya tidak mengikuti uji review siswa.

Siswa yang terpilih memiliki handphone android dan sudah diinstal aplikasi mobile learning.

Mekanisme uji coba yaitu sebagai berikut: pengembang melakukan kontak dengan siswa yang terpilih dengan bantuan aplikasi Whatsapp (WA), dimana pengembang menghubungi Whatsapp (WA) siswa dan pengembang mengajukan beberapa pertanyaan yang terkait dengan materi yang ada di aplikasi mobile learning. Terdapat 10 pertanyaan yang diajukan pengembang.

\section{Evaluasi (Evaluation)}

Evaluasi produk dilakukan pada setiap fase mulai dari tahap Desain, Pengembangan, dan Implementasi. Setelah produk divalidasi oleh para ahli berdasarkan kritik dan saran yang berikan oleh ahli media dan ahli materi, maka akan diketahui kelemahan-kelemahan dari produk. Produk perlu untuk direvisi untuk meningkatkan produk final agar siap diujicobakan kepada siswa.

\section{HASIL DAN PEMBAHASAN}

Hasil dari penelitian ini adalah aplikasi android (apk) materi Narrative Text Pelajaran Bahasa Inggris Kelas IX SMP. Aplikasi tersebut perlu diinstal di smartphone android sehingga bisa dipergunakan sebagai media mobile learning bagi siswa. Bab ini membahas analisis data penelitian, yaitu data dari validasi produk dimana produk direview oleh ahli materi, ahli media pembelajaran dan desain pembelajaran, dan hasil uji coba siswa (kelompok kecil dan kelompok besar), serta uji coba lapangan (tryout).

Hasil validasi produk media dilakukan sebelum produk diujicobakan langsung terhadap siswa. Validasi media dimaksudkan untuk mengevaluasi produk mobile learning, baik dari segi materi maupun tampilannya yang dilakukan oleh seorang ahli media dan desain serta ahli materi.

Tabel 1. Uji Kelayakan Oleh Ahli Materi

\begin{tabular}{lllll}
\hline No. Variabel & $\begin{array}{l}\text { Skor } \\
\text { Maks }\end{array}$ & Skor & $\begin{array}{l}\text { Persen- Ketera- } \\
\text { tase }\end{array}$ & ngan \\
\hline 1. Isi & 40 & 34 & $85 \%$ & Sangat Baik \\
2. Teknologi & 30 & 23 & $76 \%$ & Baik \\
3. Desain & 30 & 24 & $80 \%$ & Baik \\
& & & & \\
\hline
\end{tabular}

Tabel 1 berdasarkan hasil angket validasi Ahli Materi diperoleh hasil 85\% untuk aspek isi dan keefektifan produk mobile learning, sedangkan untuk aspek tampilan aspek teknologi diperoleh hasil 76\%, sedangkan aspek desain pesan sebesar 80\% dari total nilai maksimum 100\%. Kesimpulan dari hasil penilaian produk menurut ahli materi bahwa produk mobile learning untuk mata pelajaran Bahasa Inggris dengan materi Narrative Text baik. 
Tabel 2. Uji Kelayakan Oleh Ahli Media

Pembelajaran

\begin{tabular}{llllll}
\hline No. & Variabel & $\begin{array}{l}\text { Skor } \\
\text { Max }\end{array}$ & $\begin{array}{l}\text { Skor Persen } \\
\text { tase }\end{array}$ & $\begin{array}{l}\text { Ketera } \\
\text { ngan }\end{array}$ \\
\hline 1. & Teknologi & 50 & 48 & $96 \%$ & $\begin{array}{l}\text { Sangat } \\
\text { hil }\end{array}$ \\
2. & $\begin{array}{l}\text { Desain } \\
\text { Baik }\end{array}$ & 50 & 41 & $81 \%$ & \\
\hline
\end{tabular}

Tabel 2 berdasarkan hasil angket validasi Ahli Media diperoleh hasil 96\% untuk aspek teknologi dan keefektifan produk mobile learning, sedangkan untuk aspek desain diperoleh hasil $81 \%$ dari total nilai maksimum 100\%. Kesimpulan dari hasil penilaian produk menurut ahli media bahwa produk mobile learning untuk mata pelajaran Bahasa Inggris dengan materi Narrative Text baik.

Tabel 3. Uji Kelayakan Oleh Ahli Desain Pembelajaran

\begin{tabular}{llllll}
\hline No. Variabel & $\begin{array}{l}\text { Skor } \\
\text { Max }\end{array}$ & $\begin{array}{l}\text { Skor Persen } \\
\text { tase }\end{array}$ & $\begin{array}{l}\text { Ketera } \\
\text { ngan }\end{array}$ \\
\hline 1. & Teknologi & 50 & 44 & $89 \%$ & $\begin{array}{l}\text { Sangat } \\
\text { baik }\end{array}$ \\
2. & $\begin{array}{l}\text { Desain } \\
\text { Pesan }\end{array}$ & & 41 & $82 \%$ & Baik \\
\hline
\end{tabular}

Tabel 3 berdasarkan hasil angket validasi Ahli Desain diperoleh hasil 89\% untuk aspek teknologi dan keefektifan produk mobile learning, sedangkan untuk aspek desain diperoleh hasil $82 \%$ dari total nilai maksimum 100\%. Masukan dari ahli desain pembelajaran perlu dikembangkan untuk materi atau pokok bahasan lainnya. Peran guru tetap dibutuhkan walaupun siswa sudah memiliki aplikasi pembelajaran yang bersifat mobile (mobile learning). Desain mobile learning perlu diadaptasi untuk seluruh siswa dengan ragam kemampuannya. Ahli desain memberikan apresiasi dengan tampilan media pembelajaran yang kreatif dan menarik. Kesimpulan dari hasil penilaian produk menurut ahli media bahwa produk mobile learning untuk mata pelajaran Bahasa Inggris dengan materi Narrative Text baik.

Tabel 4. Uji Coba Kelompok Kecil

\begin{tabular}{llll}
\hline No. Variabel & Persentase & Keterangan \\
\hline 1. & Hasil Produk & $87,5 \%$ & Sangat Baik \\
2. & Keefektifan & $86,5 \%$ & Sangat Baik \\
& Produk & & \\
\hline
\end{tabular}

Tabel 4 berdasarkan hasil angket Kelompok Kecil di atas, dapat kita lihat bahwa tampilan produk mobile learning menurut penilaian siswa mendapatkan kategori sangat baik dengan persentase $87,5 \%$, sedangkan untuk aspek keefektifan produk mendapatkan nilai $86,5 \%$ dengan kategori baik. Nilai rata-rata dari penilaian Kelompok Kecil tersebut adalah 87,0\%. 
Tabel 5 Uji Coba Kelompok Besar

\begin{tabular}{llll}
\hline No. & Variabel & Persentase & Keterangan \\
\hline 1. & Hasil Produk & $88,7 \%$ & Sangat Baik \\
2. & Keefektifan & $84,6 \%$ & Baik \\
& Produk & & \\
\hline
\end{tabular}

Berdasarkan hasil angket siswa kelas IX SMP eLKISI di atas, dapat kita lihat bahwa tampilan produk mobile learning menurut penilaian siswa mendapatkan kategori sangat baik dengan persentase $88,7 \%$, sedangkan untuk aspek keefektifan produk mendapatkan nilai 84,6\% dengan kategori baik. Nilai rata-rata dari penilaian Kelompok Besar tersebut adalah 86,7\%. Melalui tabel diatas dapat disimpulkan bahwa mobile learning berbasis android dengan materi Narrative Text efektif digunakan siswa untuk membantu mengatasi kesulitan belajar.

\section{Penerapan Produk Dalam Pembelajaran}

Produk mobile learning diujicobakan pada 6 siswa kelas IX International 1 dengan materi Narrative Text. Uji coba ini dilakukan dengan tujuan untuk mengetahui kekurangan dan kelemahan dari produk mobile learning, serta menguji keefektifannya bila digunakan oleh siswa yang dituju. Proses pembelajaran untuk pengujian produk mobile learning diawali dengan guru memberikan pengantar materi dengan pokok bahasan narrative text kepada siswa. Setelah dirasa cukup memberikan apersepsi awal, guru kemudian menjelaskan tentang produk mobile learning dan cara penggunaanya. Siswa diberikan kebebasan untuk memilih materi yang sudah tersedia di dalam mobile learning, guru juga memberikan arahan apabila masih ada materi yang kurang dipahami.

Tahap implementasi ini dilakukan dengan melakukan Uji coba secara riil penggunaan aplikasi android di handphone siswa. Karena produk pengembangan merupakan mobile learning, penggunaan mobile learning tersebut idealnya adalah dilakukan oleh siswa secara mandiri, tanpa ada batasan lokasi maupun waktu. Sehingga pengujian dilakukan di luar jam sekolah dengan mengambil sampel 6 siswa yang sebelumnya tidak mengikuti uji review siswa. Siswa yang terpilih memiliki handphone android dan sudah diinstal aplikasi mobile learning.

Mekanisme uji coba yaitu sebagai berikut: pengembang melakukan kontak dengan siswa yang terpilih dengan bantuan aplikasi Whatsapp (WA), dimana pengembang menghubungi Whatsapp (WA) siswa dan pengembang mengajukan beberapa pertanyaan yang terkait dengan materi yang ada di aplikasi mobile learning.

Tabel 6. Rekapitulasi Pertanyaan dan Jawaban Uji Coba Lapangan (tryout) 
No. Variabel Persen Keterangan

\begin{tabular}{llll}
\hline 1. & Keterlibatan & $100 \%$ & Sangat Baik \\
2. & Keefektifan & $85 \%$ & Sangat Baik \\
& Prndık & & \\
3. & Hasil Produk & $91,5 \%$ & Sangat Baik \\
4. & Keefektifan & $84,6 \%$ & Sangat Baik \\
& Produk & & \\
\hline
\end{tabular}

Pengamatan secara langsung berfungsi untuk mengetahui proses pembelajaran siswa di dalam kelas, baik dengan metode penggunaan mobile learning berbasis android maupun dengan metode konvensional serta untuk mengetahui respon siswa terhadap pemanfaatan mobile learning tersebut. Berdasarkan hasil pengamatan yang diperoleh, siswa yang menggunakan bantuan mobile learning berbasis android sebagai media penunjang pembelajaran, siswa terlihat lebih aktif dan dapat mengikuti pembelajaran dengan baik karena siswa telah memiliki materi yang dapat dipelajari sebelumnya. Guru hanya memberikan pendampingan dan siswa melakukan pembelajaran mandiri dengan bantuan mobile learning berbasis android. Kesimpulan dari hasil pengamatan tersebut bahwa mobile learning berbasis android dengan materi Narrative Text adalah sangat layak digunakan siswa untuk membantu mengatasi kesulitan belajar.

Penggunaan mobile learning menjadikan pembelajaran Bahasa Inggris khususnya pokok bahasan narrative text semakin menarik dan siswa dapat belajar secara mandiri di luar jam pembelajaran formal.

\section{KESIMPULAN}

Kesimpulan yang bisa didapatkan dari penelitan dan pembahasan yang telah dilakukan adalah sebagai berikut:

1. Memproduksi mobile learning berbasis android sangat diperlukan dalam menunjang proses pembelajaran Bahasa Inggris pokok bahasan Narrative Text. Penerapan mobile learning berbasis android dapat menumbuhkan semangat belajar siswa dan memudahkan guru dalam menyampaikan materi pelajaran. Proses produksi mobile learning diawali dengan melakukan penelitian dan pengumpulan informasi, menganalisis kebutuhan siswa, mendesain produk, validasi desain, revisi, dan uji coba produk.

2. Keunggulan produk mobile learning berbasis android dibandingkan dengan media pembelajaran lainnya pada saat dimanfaatkan dalam proses pembelajaran diantaranya:

a. Mobile learning berbasis android dapat digunakan kapan saja dan dimana saja tanpa batasan waktu dan tempat.

b. Mobile learning berbasis android mudah dioperasikan, karena menggunakan menu-menu yang sederhana. 
c. Ukuran tampilan mobile learning berbasis android menyesuaikan tampilan layar smartphone penggunanya.

d. Mobile learning berbasis android tanpa biaya, karena mobile learning bersifat offline.

e. Mobile learning berbasis android memiliki tampilan visual yang menarik, sehingga meningkatkan minat belajar siswa.

B. Saran

Berdasarkan simpulan di atas, dari penelitian ini dapat diajukan beberapa saran sebagai berikut:

1. Bagi guru, pengembangan mobile learning berbasis android dengan materi Narrative Text dapat dikembangkan pada materi lain dengan karakteristik yang sama.

2. Bagi peneliti lain, penelitian ini dapat dilanjutkan pada populasi yang lebih luas dengan jangka waktu yang lebih lama sehingga hasil yang diperoleh lebih maksimal.

\section{REFERENSI}

Dickins, P. R. Evaluation (Language Teaching : a Scheme for Teacher Education). Oxford: Oxford University Press. 1993.

Iversen, J., \& Eierman, M. Learning Mobile App Development A Hands-on Guide to Building Apps with iOS and Android. Indiana: Addison-Wesley, 2014.

Iversen, J., \& Eierman, M. Learning Mobile App Development A Hands-on Guide to Building Apps with iOS and Android. Indiana: Addison-Wesley, 2014.

Kukulska, A., \& Hulme. Will Mobile Learning Change Language Learning? European Association for Computer Assisted Language Learning, 157-165, 2009.

Kukulska, H., \& Traxler, J. Mobile Learning A handbook for educators and trainers. London: Routledge, 2005.

Setyosari, P. Metode Penelitian Pendidikan \& Pengembangan. Jakarta: KENCANA, 2013.

Smaldino, S. E. Instructional Technology and Media for Learning. New Jersey: Pearson Merrill Prentice Hall, 2003.

Socket, G. New Language Learning \& Teaching Environments The Online Informal Learning of English. Paris: Pagrave Macmillan, 2014. 